\title{
BIOMASS YIELD AND QUALITY OF FODDER FROM SELECTED VARIETIES OF LABLAB (Lablab Purpureus L) IN NANDI SOUTH SUB-COUNTY OF KENYA
}

\author{
Anthony Juma WANGILA ${ }^{1 \otimes}$, Charles Karuku GACHUIRI ${ }^{1}$, James Wanjohi MUTHOMI ${ }^{1}$ and John Okeyo OJIEM ${ }^{2}$ \\ ${ }^{1}$ Department of Animal Production, University of Nairobi, College of Agriculture and Veterinary Sciences, Nairobi, Kenya \\ ${ }^{1}$ Department of Plant Science and Crop Protection, University of Nairobi, College of Agriculture and veterinary sciences, Nairobi, Kenya \\ ${ }^{2}$ Kenya Agricultural and Livestock Research Organization, (KALRO) Kibos, Horticulture Research Center, Kenya \\ Email; anthonywangila94@gmail.com; ORCID: 0000-0001-9114-9625 \\ supporting Information
}

\begin{abstract}
Low quality feeds is the main challenge ailing livestock production among the small-scale farmers in the tropics. Cheaper sources of alternative high quality fodder supplements are needed to improve livestock productivity. The objective of this study was to determine biomass yield and quality of fodder from selected lablab varieties. Eight lablab varieties namely, DL1002, Ngwara Nyeupe, Echo-Cream, Black-Rongai, Eldo-KtCream, Eldo-Kt-Black1, Brown Rongai and Eldo-Kt-Black2 were established in three sites of Nandi south sub county, Kenya. Randomized complete block design was used at farm level with four replications per site. Data on biomass yield, chemical composition and in vitro-dry matter digestibility of the eight lablab forages was collected. Biomass yield differed significantly among the lablab varieties ranging from 5.6-12.6 $\mathrm{t} \mathrm{DM} / \mathrm{ha}$ across the three sites. Highest biomass yield was recorded for Brown Rongai (12.6 t DM/ha) and lowest with DL1002 (5.6 t DM/ha). Crude protein (CP) content varied significantly between varieties with sites ranging from 19.6$23.9 \mathrm{~g} / 100 \mathrm{~g}$. Highest CP was recorded with Eldo-Kt-Cream and Black Rongai $(23.9 \mathrm{~g} / 100 \mathrm{~g}$ and $23.7 \mathrm{~g} / 100 \mathrm{~g})$ across the three sites. For all the varieties, Neutral detergent fibre (NDF) ranged from 44.4-48.6 g/100g, acid detergent fibre (ADF) 31.6-35.7 g/100g and acid detergent lignin (ADL) 9.0-11.9 g/100g across the three sites. Highest NDF was recorded with DL1002 (48.6 g/100g), ADF with Eldoret-Kitale-Black2 (35.9 g/100g) and acid detergent lignin with DL1002 (11.7 g/100g). In vitro dry matter digestibility (IVDMD) varied significantly between varieties and sites ranging from 67.6-75.7 g/100g between the varieties across the three sites. Eldo-Kt-cream and Black Rongai had the highest IVDMD (75.7 and $74.4 \mathrm{~g} / 100 \mathrm{~g})$ across the three sites. Eldoret-Kitale-Cream and Black Rongai varieties had better dry matter yield, crude protein and low fibre fractions compared to the other varieties signifying their potential to be recommended as supplement to low quality fodder by small-scale farmers.
\end{abstract}

Keywords: Biomass yield, Digestibility, Feed, Fodder, Lablab.

\section{INTRODUCTION}

In Kenya, livestock contributes over 12\% to the Growth Domestic Product (GDP) and accounts for 47\% of Agricultural GDP (Kabubo-Mariara, 2008). The adequate provision of livestock feed is key to food security especially in the developing countries as animals are capable of converting low quality feedstuffs into high quality foods such as meat, milk and eggs (Amare et al., 2020). Sixty to seventy percent of livestock production costs has been attributed to feeds (Amare et al., 2020). Increase in livestock production by small-scale farmers will majorly rely on proper utilization of locally available feed resources to meet nutrient requirements (Bell et al., 2018). In Kenya, almost one-third of the small-scale farmers experience insufficient livestock feeds as the main challenge especially in dry seasons (Lukuyu et al., 2011). Most farmers feed their livestock on low quality feeds such as natural grass, maize stover, wheat straw, bean haulms and banana pseudo stems that are deficient in protein content (Abera and Berhanu, 2017; Redae and Tekle, 2020; Yiberkew et al., 2020). Production and use of fodder legumes is one of the cheaper ways of increasing both the quantity and quality of livestock feeds (Sharma et al., 2018).

Dolichos bean (Lablab purpureus L. Sweet), a vegetable crop of Asia and Africa origin (Bhardwaj and Hamama., 2019), was reported by Keerthi et al. (2015) as a good protein supplement for low quality animal feeds. This legume belongs to the family Fabaceae, sub family Faboideae, tribe phaseoleae and sub-tribe Phaseolineae (Gupta et al., 2017). The legume grows fast and can easily provide fodder within three months after planting (ILRI, 2013). It can produce approximately 4.5-20.1 tones DM/ha depending on soil fertility and rainfall distribution (Abera and Berhanu, 2017). The whole plant contain protein content of $13-24.5 \%$ varying from variety to variety (Heuzé et al., 2014; Bhardwaj and Hamama, 2019) comparable with Lucerne (15\%), Clover legume (20\%) and Fresh faba bean (14-20\%) CP (Roy et al., 2016). It is a widely cultivated, highly drought resistant legume vegetable crop that can be grown in tropics and subtropics where soil fertility is low to be used as human food, forage and as a cover crop for soil conservation (Kumar, 2017; Bhardwaj and Hamama., 2019). 
Kumar et al. (2018) observed that the use of less costly and easily available indigenous feed resources such as legume forages as opposed to commercial feeds had great ability to enhance livestock productivity. This study therefore aimed at evaluating the biomass yield and quality of varieties of Lablab purpureus as a supplement to low quality fodder.

\section{MATERIALS AND METHODS}

\section{Description of the study site}

The study was conducted in Nandi south Sub-County in the Rift Valley region of Kenya. The altitude ranges from $1,400 \mathrm{~m}$ along the border with Nyando district to $2,400 \mathrm{~m}$ ASL in the highlands. The common soil texture type is loam and clay. Temperatures range from 15 to $26^{\circ} \mathrm{C}$ and rainfall between $1200-2000 \mathrm{~mm}$ p.a. It has two rainy seasons; the long rains between March and June and the short rains between October and early December and the dry season occurs from late December to March (Onyango et al., 2016). Three sites with different climatic conditions and soil fertility were selected within Nandi South: Koibem site with temperature of $18{ }^{\circ} \mathrm{C}$, high fertile soils with nitrogen content of $0.38 \%$ and carbon of $3.91 \%$ with annual rainfall distribution of $2,000 \mathrm{~mm}$ p.a., Kiptaruswo site with temperature of $20{ }^{\circ} \mathrm{C}$ medium soil fertility with nitrogen content of $0.26 \%$, carbon content of $1.87 \%$ with annual rainfall distribution of $1,700 \mathrm{~mm}$ p.a. Kapkarer site with temperature of $22{ }^{\circ} \mathrm{C}$, low soil fertility with nitrogen content of $0.16 \%$ and carbon $1.44 \%$ with annual rainfall distribution of $1,600 \mathrm{~mm}$ p.a., respectively (Omondi et al., 2011; Landon, 2014).

\section{Experimental treatment and design}

Treatments consisted of eight varieties of lablab (L. purpureus) namely: DL1002, Ngwara Nyeupe, Echo-Cream, Black Rongai, Eldo-Kt-Cream, Eldo-Kt-Black1, Brown Rongai and Eldo-Kt-Black2. Seeds were acquired from Kenya Agricultural Livestock and Research Organization (KALRO) Kitale and were tested for viability at KALRO Kibos prior to planting. Each Lablab variety was planted in $5 \times 4 \mathrm{~m}$ plots in each of the four farms per site. The experiment was laid out in a Randomized Complete Block Design (RCBD) with each farm representing a block comprising of eight plots. Diammonium phosphate (DAP) fertilizer was applied at the rate of $30 \mathrm{Kg}$ DAP/ha mixed with the soil before seeds were sown. Lablab seeds were sown at the onset of rains at a rate of $30 \mathrm{~kg}$ seeds/ha with a spacing of $45 \mathrm{~cm}$ between rows and $30 \mathrm{~cm}$ between plants and two seeds per hill. Weeding was done twice at an interval of 21 days of emergence. Data taken included biomass yield, crude protein content, neutral detergent fibre (NDF), acid detergent fibre (NDF) and acid detergent lignin (ADL) and in vitro dry matter digestibility (IVDMD).

\section{Determination of biomass yield}

At $50 \%$ flowering, a fresh sample was harvested for each variety by randomly cutting the plants $5 \mathrm{~cm}$ above the ground from each plot to make approximately $1 \mathrm{~kg}$ for each variety per plot. The harvested materials were accurately weighed, sealed in polythene bags for oven drying at $60^{\circ} \mathrm{C}$. The rest of the plants within each plot were harvested by cutting at $5 \mathrm{~cm}$ above the ground. They were placed into gunny bags and weighed using a $100 \mathrm{~kg}$ dial scale graduated to the nearest $1 \mathrm{~kg}$ to obtain the fresh biomass yield per plot. After drying the fresh samples in an oven of $60{ }^{\circ} \mathrm{C}$ to a constant weight, the new weight was recorded and the samples were ground using a Wiley mill standard model No. 3 with sieve of $0.5 \mathrm{~mm}$. The dry matter content was then determined by drying in an oven at $105{ }^{\circ} \mathrm{C}$ for $5 \mathrm{hrs}$. Subsequently, the biomass yield (dry matter) per ha was estimated through extrapolation from the plot size by multiplying the wet weight obtained per plot by the percentage dry matter to get dry matter yield per unit area .

\section{Determination of nutrient composition}

Dried milled samples were analyzed for crude protein content following the procedure of AOAC (1995). Neutral detergent fibre (NDF), acid detergent fibre (NDF) and acid detergent lignin (ADL) were determined using the method of Van Soest et al. (1991). The two-stage in vitro dry matter digestibility was determined following the procedure of Tilley and Terry (1963).

\section{Data analysis}

The data on biomass yield per unit area, crude protein, fibre fractions and in vitro-dry matter digestibility for different L purpureus varieties were subjected to Analysis of variance (ANOVA) for variation between varieties (both within and between sites). The significant means were separated using Tukey's statistical test at a significant level of $5 \%$.

\section{RESULTS AND DISCUSSION}

\section{Biomass yield of different Lablab purpureus varieties}

Dry matter yield of the lablab varieties differed significantly $(P<0.05)$ both within and between sites except in Kapkarer site (Table 1). Within Kiptaruswo, highest dry matter yield was recorded with variety Brown Rongai and lowest with Echo-Cream. In Koibem high dry matter yield was observed with variety Brown Rongai while Eldoret-Kitale-Cream recorded lowest dry matter yield. Between sites, Echo-Cream variety recorded the highest dry matter yield in Koibem compared with Kapkarer and Kiptaruswo. Eldo-Kt-Cream recorded the highest dry matter yield in Kapkarer compared to Kiptaruswo and Koibem. The rest of the varieties had no significant differences in dry matter yields between the sites. 
Low dry matter yield was observed for early flowering varieties (40-45 days after emergence) as these varieties did not exhibit bushy growth characteristics, had fewer branches thus minimal foliage. The dry matter yields of lablab varieties within this study were within 4.5-9.6 t DM/ha reported earlier by Amole et al. (2013); Bowen et al. (2018) and Tulu et al. (2018). However the yields were higher than $4 \mathrm{t} \mathrm{DM} /$ ha reported by Hassan et al. (2014). The differences in dry matter yield in this study could be attributed to genetic variations among the lablab varieties (Amole et al., 2013; Tulu et al., 2018) or difference in rainfall distribution and soil fertility within the three sites (Omondi, et al., 2011; Kebede et al., 2016).

The between site variations could be attributed to environmental variability, variations in soil moisture content, the initial plant populations per plot and soil types as these factors were reported by Hassan et al. (2014) and Kebede et al. (2016) to cause dry matter yield fluctuations in lablab. Different soil characteristics between the three sites was reported by Omondi et al. (2011) as sandy loam soils in Kapkarer and clay soils in Kiptaruswo and Koibem, this might have also caused variation in dry matter yields of lablab between sites. In an earlier study, Landon (2014) reported that Koibem site had high, Kiptaruswo medium and Kapkarer low fertile soils. As such, the high biomass yields per unit area in Koibem could be attributed to high fertile soils that supported robust growth of lablab. This could also mean that each of the lablab varieties has different environmental adaptations in which they can derive well compared to others (Tulu et al., 2018). However, the dry matter yields obtained in this study were within the range 5-14 $\mathrm{t} \mathrm{DM/ha}$ that was reported by Hassan et al. (2014) as the satisfactory dry matter yield for good forage legume.

\section{Table 1 - Dry matter yields of Lablab Purpureus varieties in the study area}

\begin{tabular}{|c|c|c|c|c|c|}
\hline $\begin{array}{ll}\text { Lablab varieties } & \text { Sites } \\
\end{array}$ & Kapkarer & Kiptaruswo & Koibem & Mean & SE \\
\hline \multicolumn{6}{|l|}{ Ton DM /ha } \\
\hline Black-Rongai & 8.2 & $6.8^{\mathrm{abx}}$ & $8.9^{b c x}$ & $8.0^{b}$ & 1.5 \\
\hline Brown Rongai & 11.9 & $10.5^{a x}$ & $15.4^{a x}$ & $12.6^{a}$ & 2.9 \\
\hline DL1002 & 6.1 & $6.0^{a b x}$ & $4.8^{\mathrm{cx}}$ & $5.6^{b}$ & 0.7 \\
\hline Echo-Cream & 5.0 & $3.9^{\text {by }}$ & $12.1^{\mathrm{abx}}$ & $7.0^{b}$ & 1.3 \\
\hline Eldo-Kt-Black1 & 7.6 & $5.6^{b x}$ & $6.4^{\mathrm{bcx}}$ & $6.5^{b}$ & 0.9 \\
\hline Eldo-Kt Black2 & 7.2 & 7.7abx & $5.6^{\mathrm{cx}}$ & $6.8^{b}$ & 1.2 \\
\hline Eldo-Kt-Cream & 9.5 & $5.2^{\text {by }}$ & $4.4^{c y}$ & $6.3^{b}$ & 1.2 \\
\hline Ngwara Nyeupe & 6.0 & $5.5^{b x}$ & $8.7^{b c x}$ & $6.8^{b}$ & 1.7 \\
\hline Mean & $7.7^{a}$ & $6.4^{a}$ & $8.3^{a}$ & 7.5 & \\
\hline SE & 1.87 & 1.0 & 1.3 & 0.97 & \\
\hline LSD & 5.5 & 2.95 & 3.82 & 2.73 & \\
\hline$P$ Value & $0.263^{\text {ns }}$ & $0.007 * *$ & $<.001 * *$ & $<.001 * *$ & \\
\hline
\end{tabular}

\section{Crude protein of different varieties of Lablab purpureus}

The crude protein content of different lablab varieties within and between sites is shown in Table 2. Crude protein of lablab varieties varied significantly $(P<0.05)$ both within and between the sites. The mean crude protein was significantly higher with lablabs that were grown in Koibem compared to those that were grown in Kapkarer and Kiptaruswo. Kiptaruswo, highest CP was recorded with DL1002 while lowest with Brown Rongai. In Koibem site, high CP content was recorded with variety Eldo-Kt-Cream and Black Rongai while lowest with Echo-Cream. There was significant interaction of CP content between lablab varieties and sites. The CP content of similar varieties was higher in Koibem compared with same in Kapkarer and Kiptaruswo. Across the three sites, Eldo-Kt-Cream and Black-Rongai had the highest mean crude protein content while Brown Rongai and Echo-Cream variety had the lowest.

In general, crude protein content of the eight lablab varieties in this study ranged from 18.0 to $26.5 \mathrm{~g} / 100 \mathrm{~g}$. This was in agreement with results from other studies (18-23 g/100g) when the whole lablab plant was harvested at $50 \%$ flowering (Heuzé et al., 2014; Tulu et al., 2018; Bhardwaj and Hamama, 2019). Lower CP content of the whole lablab plant has also been reported in various studies ranging from 15-17 g/100g (Mbuthia et al., 2003; Njarui et al., 2003 and Mapiye et al., 2007). Crude protein is one of the indices that is usually used to assess the feed quality (Liu et al., 2019). The variability of CP content in lablab varieties in this study enables us to choose the suitable variety that can be used as a supplement for low quality forges (Geleti et al., 2013). The variations in crude protein content among the varieties of lablab and across the sites in this study and with those by others was attributed to difference in genotypes and soil fertility (Geleti et al., 2013; Kebede et al., 2016; Tulu et al., 2018; Washaya et al., 2018). Additionally, the low crude protein content in Brown Rongai variety could be explained by observation by Washaya et al. (2018) that biomass yield of legume forages were negatively correlated with their quality. According to Kazemi et al. (2012), legume forages with CP above $19 \%$ were considered of high quality while those with $<8 \% \mathrm{CP}$ were regarded as of low quality hence cannot be used as a supplement for low quality fodder. Tulu et al. (2018) reported that most herbaceous legumes $>15 \%$ CP could support 
growth and lactation of dairy animals. This indicates that the CP values of all lablab varieties in this study met the threshold of being used as a supplement to low quality feeds for lactating animals (Geleti et al., 2013).

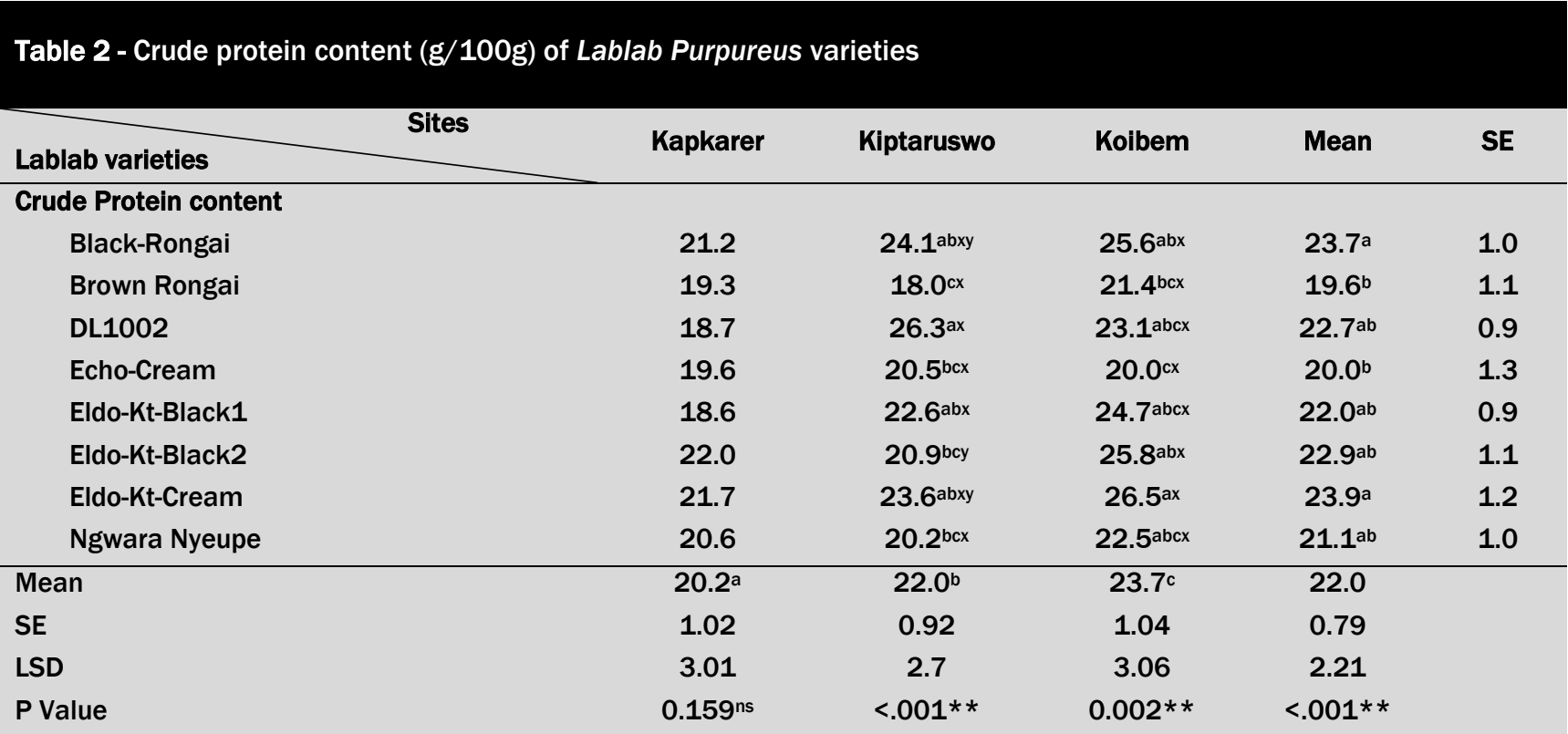

Eldo: Eldoret; Kt: Kitale; DL: Dry land variety; abcValues with different superscripts within column are significantly different; xyzValues with different superscripts within row are significantly different $(* \mathrm{P}<0.05 ; * * \mathrm{P}<0.001$; ns: Non-significant.

\section{Fibre fraction of eight selected Lablab purpureus varieties}

The fibre fractions of the eight Lablab purpureus varieties are shown in Table 3. There were significant differences $(P<0.05)$ between fibre fractions of the lablab varieties both within and between the sites. Higher neutral detergent fibre (NDF) was recorded for lablab varieties harvested in Kapkarer site (mean=51.4 g/100g) and lowest in those established in Koibem (mean=42.9 g/100g). In Kapkarer and Kiptaruswo, all the varieties had similar NDF content unlike in Koibem site. In Koibem, DL1002 variety had the highest NDF while lowest recorded with varieties; Echo Cream and Black-Rongai respectively. Between the sites, NDF content of all the lablab varieties varied significantly except DL1002 which had similar NDF content within the three sites. Across the three sites, DL1002 had the highest NDF while Black-Rongai variety had the lowest. Eldo-Kt-Black2 recorded the highest acid detergent fibre (ADF) in Kapkarer site while Eldo-Kt-Black1 had the lowest. In Kiptaruswo, highest ADF was recorded with Eldo-Kt-Cream and lowest with Black Rongai. Within Koibem site, high ADF was recorded with Black Rongai variety and lowest with Eldo-Kt-Cream. The ADF content of the varieties varied significantly between sites except DL1002 and Ngwara Nyeupe. Across the three sites, highest ADF was recorded with Eldo-Kt-Black2 with Eldoret-Kitale-Cream having the lowest. Within Kapkarer site, Eldo-Kt-Cream had the highest acid detergent lignin (ADL) and Eldo-Kt-Black1 the lowest. In Kiptaruswo, no significant variation was observed in ADL content among the varieties of lablab. Within Koibem, Eldo-Kt-Black1 had the highest ADL and Echo Cream the lowest. Between the sites, Eldo-Kt-Black1 recorded the highest ADL in Koibem and Kiptaruswo than in Kapkarer. Eldo-Kt-Cream had the highest ADL in Kapkarer than in Koibem. In general, high ADL was observed for Eldo-Kt-Cream with Echo Cream having the lowest across the three sites.

The NDF content of the eight lablab varieties in this study ranged from $44.4 \mathrm{~g} / 100 \mathrm{~g}$ and $48.6 \mathrm{~g} / 100 \mathrm{~g}$ across the three sites. Similarly, NDF content of the whole lablab plant 45-48 g/100g has been reported by others (Heuzé et al., 2014; Bhardwaj and Hamama, 2019). However, lower NDF content of 40.09 and $39.0 \mathrm{~g} / 100 \mathrm{~g}$ for the whole lablab plant was reported by Ahmad et al. (2000) and Mbuthia et al. (2003). The whole fiber fraction of fodder is confined in the NDF or cell walls and it gives the best approximation of the entire fiber content of a feed. The neutral detergent fibre is negatively associated with feed intake with its increase in forage reduces feed consumption (Garcia et al., 2003). The study by Geleti et al. (2013) and Yiberkew et al. (2020) indicated that, forage plants with NDF content less than 45\% were regarded as of high quality while those between $45-65 \%$ were medium quality and above $65 \%$ as low quality forage. Profile of NDF content from the eight lablab varieties in this study were of high quality in Koibem sites while Kapkarer and Kiptaruswo were of medium quality. Therefore, all the lablab varieties in this study had acceptable NDF content for ruminant animals.

The variation in NDF content between varieties of lablab in this study could also be due to genetic variations among the lablab varieties that were used (Amole et al., 2013). The between site variations in NDF content could be due to variation in soil fertility between the sites. Studies by Turk (2010); Kebede et al. (2016) and Yiberkew et al. (2020) indicated that, fertile soils increases the forage dry matter yield and crude protein content which results in reduction of NDF and ADF content by accumulation of more foliage than structural features. This observation is consistent with the results of NDF content of lablab varieties in in this study/ Koibem site, with higher fertile soils, had lablab with lower NDF content compared to Kapkarer site. 
Table 3 - Fibre fractions (\%) of various Lablab purpureus varieties grown in the study area

\begin{tabular}{|c|c|c|c|c|c|c|c|c|c|c|c|c|c|c|c|}
\hline \multirow{2}{*}{ Varieties of lablab } & \multicolumn{5}{|c|}{$\%$ Neutral detergent fibre (NDF) } & \multicolumn{5}{|c|}{$\%$ Acid detergent fibre (ADF) } & \multicolumn{5}{|c|}{$\%$ Acid detergent lignin } \\
\hline & Kap & Kip & Koi & Mean & SE & Kap & Kip & Koi & Mean & SE & Kap & Kip & Koi & Mean & SE \\
\hline Black Rongai & 49.5 & 43.2 & $40.4^{\text {cy }}$ & $44.4^{b}$ & 0.97 & 33.0 bcy & $28.7^{\mathrm{cy}}$ & $45.4^{\mathrm{ax}}$ & $35.7^{\mathrm{ab}}$ & 1.8 & $9.8^{\mathrm{abx}}$ & 9.1 & $9.8^{a b x}$ & $9.6^{\mathrm{ab}}$ & 1.2 \\
\hline Brown Rongai & 53.2 & 49.4 & 41.1 cy & $47.9^{\mathrm{ab}}$ & 0.94 & $34.4^{\mathrm{bx}}$ & $36.2^{\mathrm{abx}}$ & $28.3^{\text {bcy }}$ & $33.0^{\mathrm{ab}}$ & 1.2 & $9.3^{\mathrm{abx}}$ & 9.7 & $11.2^{\mathrm{abx}}$ & $10.1^{\mathrm{ab}}$ & 0.8 \\
\hline DL1002 & 52.2 & 46.7 & $47.0^{\mathrm{ax}}$ & $48.6^{a}$ & 2.13 & $33.8^{\mathrm{bcx}}$ & $30.1^{\mathrm{cx}}$ & $34.4^{\mathrm{bx}}$ & $32.8^{\mathrm{ab}}$ & 1.9 & $12.7^{\mathrm{ax}}$ & 11.6 & $10.8^{\mathrm{abx}}$ & $11.7^{a}$ & 1.2 \\
\hline Echo Cream & 49.5 & 45.1 & $40.4^{\text {cy }}$ & $45.0^{\mathrm{ab}}$ & 1.23 & 32.4bcy & $29.4^{d y}$ & $41.8^{a x}$ & $34.5^{\mathrm{ab}}$ & 1.1 & $9.6 \mathrm{abx}$ & 9.5 & $8.0^{b x}$ & $9.0^{b}$ & 0.7 \\
\hline Eldo-Kt-Black1 & 50.0 & 43.8 & $45.9^{a b x y}$ & $46.6^{\mathrm{ab}}$ & 1.66 & $28.5^{\text {cy }}$ & $34.6 \mathrm{abx}$ & $33.4^{b x}$ & $32.2^{\mathrm{ab}}$ & 1.3 & $7.3^{\text {by }}$ & 10.0 & $12.1^{\mathrm{ax}}$ & $9.8^{\mathrm{ab}}$ & 0.8 \\
\hline Eldo-Kt-Black2 & 55.5 & 46.1 & $43.3^{\text {bcy }}$ & $48.3^{a b}$ & 1.99 & $42.1^{\mathrm{ax}}$ & $35.1^{\text {aby }}$ & $30.4^{\mathrm{bcz}}$ & $35.9 \mathrm{a}$ & 0.8 & $11.3^{a b x}$ & 12.2 & $11.1^{\mathrm{abx}}$ & $11.5^{a}$ & 0.4 \\
\hline Eldo-Kt-Cream & 53.0 & 46.1 & $41.4^{\mathrm{cz}}$ & $46.8^{\mathrm{ab}}$ & 0.55 & $33.4^{b c x}$ & $37.0^{\mathrm{ax}}$ & $24.4^{\text {cy }}$ & $31.6^{b}$ & 0.9 & $13.3^{\mathrm{ax}}$ & 12.2 & $10.1^{\text {aby }}$ & $11.9^{a}$ & 0.9 \\
\hline Ngwara Nyeupe & 48.5 & 44.6 & 43.6 $6^{a b c y}$ & $45.5^{\mathrm{ab}}$ & 0.93 & $33.5^{b c x}$ & $31.2^{b x}$ & $33.7^{b x}$ & $32.8^{\mathrm{ab}}$ & 1.0 & 11.19ab & 10.6 & $10.1^{\mathrm{abx}}$ & $10.6^{a b}$ & 0.6 \\
\hline Mean & $51.4^{a}$ & $45.6^{b}$ & $42.9^{c}$ & 46.6 & & $33.9 \mathrm{a}$ & $32.8^{a}$ & $34^{a}$ & 33.6 & & $10.6^{a}$ & $10.6^{a}$ & $10.4^{a}$ & 10.5 & \\
\hline SE & 1.62 & 1.85 & 0.77 & 1.48 & & 1.17 & 1.92 & 1.49 & 1.51 & & 0.88 & 1.05 & 0.74 & 0.88 & \\
\hline LSD & 4.76 & 5.44 & 2.26 & 4.19 & & 3.44 & 5.64 & 4.4 & 4.26 & & 2.58 & 3.08 & 2.19 & 2.47 & \\
\hline P Value & $0.072^{\text {ns }}$ & $0.393^{\text {ns }}$ & $<.001 * *$ & $<.001 * *$ & & $\begin{array}{c}<.001 * \\
\star\end{array}$ & 0.026 * & $\begin{array}{c}<.001^{*} \\
\star\end{array}$ & $<.001^{*}$ & & $0.002 * *$ & $\begin{array}{c}0.251 \\
\text { ns }\end{array}$ & $0.033^{*}$ & $\begin{array}{c}0.001 * \\
*\end{array}$ & \\
\hline
\end{tabular}

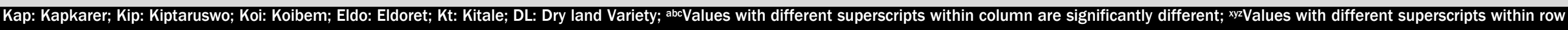

are significantly different $\left({ }^{*} \mathrm{P}<0.05 ; * * \mathrm{P}<0.001\right)$; ns: Non-significant 
The range in ADF content for all the varieties of lablab in this study was $31.6 \mathrm{~g} / 100 \mathrm{~g}$ to $35.7 \mathrm{~g} / 100 \mathrm{~g}$. These values were in agreement with 33-35 g/100g ADF reported earlier in the whole lablab forage by several authors (Heuzé et al., in 2014; Washaya et al., 2018; Bhardwaj and Hamama, 2019). Lower ADF content of 25-28 g/100g in lablab fodder was also reported by Ahmad et al. (2000) and Mbuthia et al. (2003). Acid detergent fibre is an indication of the degree of cellulose and lignin in forage. It is negatively associated with general digestibility; high ADF feed is less digestible (Garcia et al., 2003). The difference in ADF content among the varieties of lablab could be due to genetic variation among the varieties. According to Kazemi et al. (2012), legume forage with less than 31\% ADF content was regarded as of high quality, while that greater than 55\% NDF was regarded as poor quality. Conversely, Geleti et al. (2013) and Yiberkew et al. (2020) noted that, forage plant with less than $40 \%$ ADF was regarded as of high quality while those with greater than $40 \%$ as of poor quality. The ADF values of all the lablab varieties in this study therefore were of high quality.

The lignin content of the lablab varieties in this study ranged from 9.0 to $11.9 \mathrm{~g} / 100 \mathrm{~g}$. These were within the range of 6.3 to $13.7 \mathrm{~g} / 100 \mathrm{~g}$ reported in the whole lablab plant by several authors (Ahmad et al., 2000; Heuzé et al., 2014; Bhardwaj and Hamama, 2019). Lignin is a polymer fraction of the plant cell walls that offers rigidity and mechanical support to plants and is not digestible by animal enzymes. It increases with plant maturity and was reported to be greater when the same plant species are established under warm weather conditions (Garcia et al., 2003). The figures of ADL content for the eight lablab varieties were close and some beyond the maximum level of $10 \%$ that is required to limit forage use by ruminant animals in this study (Geleti et al., 2013; Yiberkew et al., 2020). The difference in lignin content among the varieties of lablab in this study might be due to genetic differences between the varieties and different climatic conditions within the three sites (Amole et al., 2013; Kebede et al., 2016).

\section{In vitro dry matter digestibility of different lablab varieties}

In vitro-dry matter digestibility (IVDMD) of the different $L$. purpureus varieties is shown in Table 4. The IVDMD differed significantly $(P<0.05)$ among the varieties both within and between the sites apart from in Kapkarer. Of the three sites, highest mean dry matter digestibility was recorded for varieties that were established at Koibem site compared to those established in Kapkarer and Kiptaruswo. At Kiptaruswo site high dry matter digestibility was recorded for Eldo-Kt-Cream and Black-Rongai variety with the lowest for Eldo-Kt-Black2. In Koibem, high dry matter digestibility was recorded with Eldo-Kt-Cream and Black Rongai variety, while lowest was DL1002. Between the sites, all the varieties, except Eldo-KtBlack1, varied significantly in IVDMD. Across the three sites, highest dry matter digestibility was recorded for Eldo-KtCream and Black Rongai while lowest for DL1002, Brown Rongai and Ngwara Nyeupe.

\section{Table 4 - In vitro-dry matter digestibility (\%) of Lablab varieties grown in different sites}

\begin{tabular}{|c|c|c|c|c|c|}
\hline Lablab varieties & Kapkarer & Kiptaruswo & Koibem & Mean & SE \\
\hline \multicolumn{6}{|c|}{ In vitro-dry matter digestibility } \\
\hline Black Rongai & 68.6 & 75.3ay & $79.4^{a b x}$ & $74.4^{\mathrm{ab}}$ & 0.64 \\
\hline Brown Rongai & 69.4 & $60.5^{\mathrm{bcz}}$ & $73.7 \mathrm{bx}$ & $67.8^{b}$ & 0.97 \\
\hline DL1002 & 69.2 & $72.1^{\mathrm{ax}}$ & 61.4 cy & $67.6^{b}$ & 1.67 \\
\hline Echo Cream & 68.6 & $71.7^{\text {ay }}$ & $76.5^{\mathrm{abx}}$ & $72.3^{\mathrm{ab}}$ & 1.09 \\
\hline Eldo-Kt-Black1 & 68.3 & $71.2^{\mathrm{ax}}$ & $74.8 \mathrm{abx}$ & $71.4^{\mathrm{ab}}$ & 2.13 \\
\hline Eldo-Kt-Black2 & 72.5 & $59.6^{c y}$ & $75.8^{a b x}$ & $69.3^{\mathrm{ab}}$ & 2.15 \\
\hline Eldo-Kt-Cream & 70.3 & 76.3 аху & $80.4^{a x}$ & $75.7^{a}$ & 1.54 \\
\hline Ngwara Nyeupe & 69.6 & $70.6 \mathrm{abx}$ & $65.4^{\text {cy }}$ & $68.5^{b}$ & 1.36 \\
\hline Mean & $69.6^{b}$ & $69.7^{b}$ & $73.4^{a}$ & 70.9 & \\
\hline SE & 1.58 & 2.22 & 1.2 & 1.62 & \\
\hline LSD & 4.66 & 6.52 & 3.53 & 4.54 & \\
\hline P Value & $0.663^{\text {ns }}$ & $<.001^{* *}$ & $<.001^{* *}$ & $0.002^{* *}$ & \\
\hline
\end{tabular}

Eldo- Eldoret, Kt- Kitale, DL- Dry land Variety, abcValues with different superscripts within column are significantly different xyzValues with different superscripts within row are significantly different $(* \mathrm{P}<0.05 ; * * \mathrm{P}<0.001)$, ns:Non-significant.

The in vitro-dry matter digestibility of various lablab that were tested in this study ranged from 67.6 to $75.7 \mathrm{~g} / 100 \mathrm{~g}$ across the three sites. Mapiye et al. (2007) reported the in vitro-dry matter digestibility of the whole lablab plant to range from 55 to $76 \mathrm{~g} / 100 \mathrm{~g}$ in agreement with those obtained in this study. However Ahmad et al. (2000) and Tulu et al. (2018) reported a lower dry matter digestibility of lablab foliage as 39.7-50.9 g/100g. The variation in IVDMD in this study with other authors could be due to difference in varieties of lablab that were used and their fibre content (Meale et al., 2012; Tulu et al., 2018). The fibre fractions in legume forages has been the major challenge in their adequate utilization in animal nutrition (Washaya et al., 2018). The high fibre fractions in a forage leads to low dry matter intake and digestibility as opposed to lower fibre fractions (Washaya et al., 2018). Varieties with high dry matter digestibility in this study such as Eldo-Kt-Cream and Black-Rongai were associated with high crude protein that increased microbial activities for organic 
matter breakdown low NDF, ADF and ADL content. Varieties with low dry matter digestibility such as DL1002, Ngwara Nyeupe and Brown Rongai were associated with high NDF, ADF and ADL and late maturity. The difference in dry matter digestibility could also be attributed to genetic differences among the lablab varieties and the climatic conditions of the location where plants within cool environment are associated with high dry matter digestibility as opposed to warm environment (Baloyi et al., 2013).

\section{CONCLUSION}

From the study, it can be concluded that biomass yield and nutrient content varied with lablab variety and production site. According present findings, variety Brown-Rongai was suitable for all sites and can be recommended as a supplement to low quality animal fodder.

\section{DECLARATIONS}

Corresponding author's E-mail: anthonywangila94@gmail.com

\section{Author's contribution}

Due to site variation with biomass yields of lablab varieties, Kapkarer farmers can grow Brown-Rongai, EldoretKitale-Cream and Black-Rongai, all authors has similar attempts in all process of conduction and writing of present study.

\section{Acknowledgements} the study.

The authors wish to acknowledge the McKnight Foundation under the project of Multipurpose Legumes for funding

\section{Conflict of interests}

The author declare that there is no conflict of interests on this work

\section{REFERENCES}

Abera M and Berhanu T (2017). Farmers' preference for improved grasses and legume forage species in six mixed farming system districts of southern region of Ethiopia. Agricultural Science and Practice. 4(2): 23-27.DOI: https://doi.org/10.15407/agrisp4.02.023 I Google Scholar

Ahmad Z, Ghafoor A and Ali A (2000). Evaluation of three exotic legume species for fodder potential. Pakistan Journal of Biological Sciences, 3: 2079-2081. DOI: https://dx.doi.org/10.3923/pjbs.2000.2079.2081 I Google Scholar

Amare G, Kebede B and Korji D (2020). Pre-extension demonstration of selected lablab varieties at midlands of Guji Zone, Southern Oromia, Ethiopia. International Journal of Research in Agriculture and Forestry. 7(7): 08-12. http://www.ijraf.org/papers/v7-i7/2.pdf I Google Scholar

Amole TA, Oduguwa BO, Shittu O, Famakinde A, Okwelum N, Ojo VOA and Adebiyi AO (2013). Herbage yield and quality of Lablab purpureus during the late dry season in western Nigeria. Slovak Journal of Animal Science. 46(1): $22-30$. https://sjas.ojs.sk/sjas/article/view/241 I Google Scholar

Association of official analytical chemists (AOAC) (1995). Revision March 1998. Official methods of analysis. Arlington Virginia. https://www.cabdirect.org/cabdirect/abstract/19720492404 or Google Scholar

Baloyi BM, Ayodele VI and Addo-Bediako A (2013). Effects of leaf harvest on crude protein and mineral contents of selected early maturing lines of lablab (Lablab purpureus). African Journal of Agricultural Research, 8(5): 449-453. DOI: https://doi.org/10.5897/AJAR12.1209 I Google Scholar

Bell LW, Moore A D and Thomas D T (2018). Integrating diverse forage sources reduces feed gaps on mixed crop-livestock farms. Animal. 12(9): 1967-1980. DOI: https://doi.org/10.1017/s1751731117003196 I Google Scholar

Bhardwaj HL and Hamama A A (2019). A preliminary evaluation of lablab biomass productivity in Virginia. Journal of Agricultural Science. 11: 42-47. DOI: https://doi.org/10.5539/jas.v11n13p42 I Google Scholar

Bowen MK, Chudleigh F, Buck S and Hopkins K (2018). Productivity and profitability of forage options for beef production in the subtropics of northern Australia. Animal Production Science. 58(2):332-342. http://dx.doi.org/10.1071/AN16180 I Google Scholar

Garcia A, Thiex N, Kalscheur K and Tjardes K (2003). Interpreting hay and haylage analysis. Interpreting Hay and Haylage Analysis .Extension Extra Archives. 103. https://openprairie.sdstate.edu/extension_extra/103 I Google Scholar

Geleti D, HailemariamM, Mengistu A and Tolera A (2013). Nutritive value of selected browse and herbaceous forage legumes adapted to medium altitude subhumid areas of western Oromia, Ethiopia. Global Veterinaria. 11(6): 809-816. https://www.idosi.org/gv/gv11(6)13/19.pdf I Google Scholar

Gupta M, Rao KP and Rajwade VB (2017). Correlation study of floral traits, yield and nutritional parameters in dolichos bean ( Lablab purpureus L .) genotypes under Allahabad agro climatic zone. Journal of Pharmacognosy and Phytochemistry. 6(6):1585-1591. https://www.phytojournal.com/archives/2017/vol6issue6/PartV/6-4-319-397.pdf I Google Scholar

Hassan MR, Amodu JT, Muhammad IR, Jokthan GE, Abdu SB, Abdullahi B, Adamu HY, Musa A, Sani I and Akpensuen TT (2014). Forage yield and quality of Lablab (Lablab purpureus L. Sweet) intercropped with maize (Zea mays L.) with flooded irrigation system in the semi-arid zone of Nigeria. Journal of Agricultural Science. 6(11): 196-211. Dol: https://doi.org/10.5539/jas.v6n11p196 I Google Scholar

Heuzé V, Tran G, Noziere P, Renaudeau D, Lessire M and Lebas F (2014). Oats. Feedipedia, a program by National Institute of Agronomic Research (INRA), Center for International Cooperation in Agricultural Research for Development (CIRAD), French Association of Zootechnics (AFZ) and Food and Agriculture Organization (FAO), Rome. https://hal.inrae.fr/hal-02796509 I Google Scholar

International Livestock Research Institute (ILRI) (2013). Lablab (Lablab purpureus cultivar Rongai) for livestock feed on small-scale farms. International livestock research institute forage factsheet, Nairobi, Kenya. http://www.ijraf.org/papers/v7-i7/2.pdf I Google Scholar 
Kabubo-Mariara J (2008). The economic impact of global warming on livestock husbandry in Kenya: a Ricardian analysis. In 16 th Annual Conference of the European Association of Environmental and Resource Economists, Gothenburg, Sweden. Pp. 25-28. https://www.afdb.org/fileadmin/uploads/afdb/Documents/Knowledge/30753359-EN-133-Kabubo-Mariara.Pdf I Google Scholar

Kazemi M, Tahmasbi AM, Naserian AA, Valizadeh R, and Moheghi MM (2012). Potential nutritive value of some forage species used as ruminants feed in Iran. African Journal of Biotechnology. 11(57): 12110-12117. D0I: https://doi.org/10.5897/AJB12.286 I Google Scholar

Kebede G, Assefa G, Feyissa F, and Mengistu A (2016). Forage legumes in crop-livestock mixed farming systems: A review. International Journal of Livestock Research. 6: 1-18. https://www.bibliomed.org/?mno=217489 I Google Scholar

Keerthi CM, Ramesh S, Byregowda M, Chandrakant N, Vaijayanthi PV, Shivakumar MS and Mohan Rao A (2015). Epistasis-driven bias in the estimates of additive and dominance genetic variance in Dolichos Bean (Lablab Purpureus L.) Var. Lignosus. Journal of Crop Improvement, 29(5):542-564. DOI: https://doi.org/10.1080/15427528.2015.1057311 I Google Scholar

Kumar A (2017). Quantitative analysis of some germplasms of lablab bean in Uttar Pradesh. International Journal of Environment, Agriculture and Biotechnology. 2(1): 40-45. http://dx.doi.org/10.22161/ijeab/2.1.7 I Google Scholar

Kumar R, Kumar D, Datt C, Makarana G and Yadav M R (2018). Forage yield and nutritional characteristics of cultivated fodders as affected by agronomic interventions: A Review. Indian Journal of Animal Nutrition, 35(4): 373-385. DOI:http://dx.doi.org/10.5958/2231-6744.2018.00057.9 I Google Scholar

Landon JR (2014). Booker tropical soil manual: a handbook for soil survey and agricultural land evaluation in the tropics and subtropics. Routledge encyclopedia of translation studies. Routledge. Link I Google Scholar

Liu C, Li D, Chen W, Yan L, Wu H, Meng Q, and Zhou Z (2019). Estimating ruminal crude protein degradation from beef cattle feedstuff. Scientific Reports. 9: 11368. https://doi.org/10.1038/s41598-019-47768-3 I Google Scholar

Lukuyu, B., Franzel, S., Ongadi, P.M. and Duncan, A.J., (2011). Livestock feed resources: Current production and management practices in central and northern rift valley provinces of Kenya. Livestock Research for Rural Development. $23(5)$ : 112. https://www.researchgate.net/profile/Steven_Franzel/publication/287168075 I Google Scholar

Mapiye C, MwaleM, Mupangwa JF, Mugabe PH, Poshiwa X and Chikumba N (2007). Utilisation of ley legumes as livestock feed in Zimbabwe. Tropical Grasslands. 41(2): 84. https://d1wqtxts1xzle7.cloudfront.net/46221970 I Google Scholar

Mbuthia EW, and Gachuiri CK (2003). Effect of inclusion of Mucuna pruriens and Dolichos lablab forage in Napier grass silage on silage quality and on voluntary intake and digestibility in sheep. Tropical and Subtropical Agroecosystems, 1(2-3): 123-128. http://erepository.uonbi.ac.ke/bitstream/handle/11295/10442 I Google Scholar

Meale SJ, McAllister TA, Beauchemin KA, Harstad OM and Chaves AV (2012). Strategies to reduce greenhouse gases from ruminant livestock. Acta Agriculturae Scandinavica, Section A-Animal Science. 62(4): 199-211. D0I: https://doi.org/10.1080/09064702.2013.770916 I Google Scholar

Njarui DM, Mureithi JG, Wandera FP, Muinga RW. (2003). Evaluation of four forage legumes as supplementary feed for Kenya dualpurpose goat in the semi-arid region of Eastern Kenya. Tropical and Subtropical Agroecosystems. 2(2): 65-71. http://www.redalyc.org/articulo.oa?id=93912118002 I Google Scholar

Omondi OS (2011). The potential for Njahi (Lablab Purpureus L.) in improving consumption adequacy for protein, iron and zinc in households: A Case for Nandi south District, Kenya. Ph.D Thesis, University of Nairobi. http://erepository.uonbi.ac.ke/bitstream/handle/11295/10913 I Google Scholar

Onyango M, Otieno DJ, Nyikal RA and Ojiem J (2016). An economic analysis of grain legumes profitability in Nandi County, Kenya. In African association of agricultural economists $5^{\text {th }}$ international conference. https://ideas.repec.org/p/ags/aaae16/246921.html I Google Scholar

Redae M and Tekle D (2020). Effect of intercropping dates of lablab (Lablab purpureus L.) with maize (Zea mays L.) on forage and maize grain yields. Asian Journal of Advanced Research and Reports, 13(2): 1-4. DOI: https://doi.org/10.9734/ajarr/2020/v13i230302 I Google Scholar

Roy AK, Malaviyal DR and Kaushal P (2016). Genetic improvement of fodder legumes especially dual purpose pulses. Indian Journal of Genetics and Plant Breeding. 76: 608-625. http://dx.doi.org/10.5958/0975-6906.2016.00076.6 I Google Scholar

Sharma SC, Balai RC and Sahoo A (2018). Effect of pasture type, phosphorus levels and phosphate solubilizing bacteria on forage productivity under agroforestry system in semi-arid regions. Journal of Agriculture and Ecology. 5: 42-49. http://saaer.org.in/online journal/2018/05/04.pdf I Google Scholar

Tilley JMA and Terry RA (1963). A two-stage technique for the in vitro digestion of forage crops. Grass and Forage science, 18(2): 104-111. https://elearning.unja.ac.id/pluginfile.php/285989 I Google Scholar

Tulu A, Temesgen W, Diribsa M, Keba W, Fekede G and Kumsa A (2018). Herbage yield potential, crude protein yield and feeding value of selected Lablab purpureus cultivars grown under sub-humid climatic condition of western Oromia, Ethiopia. International Journal of Academic and Applied Rsearch. 6: 93-100. http://www.bluepenjournals.org/ijaar/pdf/2018/October/Tulu_et_al.pdf I Google $\underline{\text { Scholar }}$

Turk M (2010). Effects of fertilization on root yield and quality of fodder beet (Beta vulgaris var. crassa Mansf.). Bulgarian Journal of Agricultural Science, 16(2): 212-219. http://www.agrojournal.org/16/02-11-10.pdf I Google Scholar

Van Soest PV, Robertson JB and Lewis BA (1991). Methods for dietary fiber, neutral detergent fiber, and non-starch polysaccharides in relation to animal nutrition. Journal of Dairy Science. 74(10): 3583-3597. https://www.journalofdairyscience.org/article/S00220302(91)78551-2/pdf I Google Scholar

Washaya S, Mupangwa J and Muchenje V (2018). Chemical composition of Lablab purpureus and Vigna unguiculata and their subsequent effects on methane production in Xhosa lop-eared goats. South African Journal of Animal Science, 48(3): 445-458. http://dx.doi.org/10.4314/sajas.v48i3.5 I Google Scholar

Yiberkew N, Mekuriaw Y and Asmare B (2020). Effects of fertilizer types and plant spacings on plant morphology, biomass yield and chemical composition of brachiaria hybrid mulato ii grass grown in lowlands of Northwest Ethiopia. Journal of Animal Science and Biotechnologies. 53 (1):20-35. http://spasb.ro/index.php/spasb/article/view/2590 I Google Scholar 